SABRAO Journal of Breeding and Genetics

53 (4) 737-748, 2021

http://doi.org/10.54910/sabrao2021.53.4.15

http://sabraojournal.org/

pISSN 1029-7073; eISSN 2224-8978

\title{
CHILI PEPPER GENOTYPES ASSAY APPROACH FOR RESISTANCE TO APHIS GOSSYPII (HEMIPTERA: APHIDIDAE)
}

\author{
A. DARYANTO ${ }^{1,2}$, M. SYUKUR ${ }^{1 *}$, SOBIR ${ }^{1}$, A. MAHARIJAYA ${ }^{1}$ and P. HIDAYAT ${ }^{3}$ \\ ${ }^{1}$ Department of Agronomy and Horticulture, Faculty of Agriculture, \\ Bogor Agricultural University, Indonesia \\ ${ }^{2}$ Agrotechnology Study, Gunadarma University, Indonesia \\ ${ }^{3}$ Department of Plant Protection, Faculty of Agriculture, Bogor Agricultural University, Indonesia \\ *Corresponding author email: muhsyukur@apps.ipb.ac.id \\ Email addresses of co-authors: adydaryanto@yahoo.com, awangmaharijaya@apps.ipb.ac.id, \\ phidayat@apps.ipb.ac.id, sobir@apps.ipb.ac.id
}

\begin{abstract}
SUMMARY
The cotton aphid (Aphis gossypii), is one of the most devastating insect pests for chili pepper that damages the crop and transmits several viruses. Thus far, there is no commercial chili cultivar with effective resistance to cotton aphids (CA). The present study aimed to develop a reliable and practical screening protocol in chili peppers for aphids resistance in the tropical areas. Three no-choice test methods i.e., seedling cage, detached leaf, and clip cage tests have been developed. The experiment was conducted in a randomized complete block design (RCBD) with four replications in a greenhouse at the Gunung Putri, Bogor, West Java, Indonesia. Seven chili pepper genotypes belong to the species Capsicum annuum L. provided by the Department of Agronomy and Horticulture, IPB University, Bogor, Indonesia were used in this study. Chili pepper resistance to aphids was observed through the number of aphids progeny, and aphids fecundity among the genotypes. Two chili genotypes consistently showed low infestation while other genotypes showed the highest infestation with three screening methods. All the methods have a high heritability value $(90 \%-91 \%)$, indicating that the evaluated chili genotypes could be used to determine effective screening methods. The correlation between the detached leaf and clip cage tests was significant $(r=0.84, P \leq 0.05)$. Therefore, the clip cage test could be used as a reliable and practical screening test for the assay of chili peppers resistance to CA infestation. These information will be helpful in the development of aphid resistant cultivars in the future.
\end{abstract}

Keywords: Clip cage, cotton aphids, detached leaf, no-choice tests, seedling phase

Key findings: The present study demonstrated the reliable and practical phenotypic screening tests in chili pepper (Capsicum annuum L.) resistance to cotton aphids. The clip cage test was found more accurate than the whole plant test used for screening of chili peppers for resistance to cotton aphids at the seedling stage. The seedling phase required less space, more uniformly than generative plants, and can be performed soon after sowing.

Manuscript received: September 15, 2021; Accepted: November 11, 2021.

(c) Society for the Advancement of Breeding Research in Asia and Oceania (SABRAO) 2021

Communicating Editor: Dr. Himmah Rustiami 


\section{INTRODUCTION}

Chili pepper (Capsicum annuum L.) is one of the economically important vegetable crops in the world. The chili peppers are grown both in the lowlands and highlands. There are five domesticated species in the genus Capsicum: Capsicum annuum, $C$. frutescens, $C$. baccatum, $C$. chinense, and C. pubescens. The $C$. annuum and $C$. frutescens species are widely planted in Indonesia, while C. pubescens is only grown in the highlands of Dieng Plateau, Central Java, Indonesia (Amamoto et al., 2013). The last reported data of the chili pepper grown area, production, and yield per hectare in 2019 were 300379 hectares, 2.4 million tons, and 8.67 tons $\mathrm{ha}^{-1}$, respectively (Ministry of Agriculture Republic Indonesia, 2021). Syukur et al. (2010), reported from their studies that chili pepper productivity can reach 22 tons ha ${ }^{-1}$.

Global climate change, directly and indirectly affects insect-pest populations, natural enemies, decomposers, and microorganisms (Setiawati et al., 2013). The increase in mean temperatures could enhance the growth of populations for several aphid species meanwhile increasing $\mathrm{CO}_{2}$ concentration could lead to their population dynamics was highly variable (Blanchard et al., 2019). Aphids are among insect-pests that threaten chili peppers (Parisi et al., 2020), and feed on the sieve elements of the phloem through the apoplast pathway (Nalam et al., 2019). They reproduce parthenogenically with a short generation that allows them to rapidly attain high population densities and reducing plant quality (Smith and Chuang, 2014). Aphids produce winged female progeny to facilitate dispersion to other plants, as an effective vector to transmit viral diseases, and by also having resistance to some of the insecticides. These makes them extraordinary insect pests (Nalam et al., 2019).

$$
\text { Maharani and Hidayat (2019) }
$$

reported 112 aphids species in the agricultural area of Indonesia. Two species have been reported to infest the Capsicum (Parisi et al., 2020). Green peach aphid
(GPA), Myzus persicae (Sulzer), infest the Capsicum in midland to the highland areas, while cotton aphids (Aphis gossypii Glover) infest the Capsicum species in lowland and the humid regions (Satar et al., 2008). Cotton aphids (CA) were reported to reduce chili pepper production up to $65 \%$ if not controlled chemically (Fereres et al., 1996). In addition, CA as also reported to serve as vectors for 50 types of viruses in the Solanaceae family (Shannag et al., 2007; da-Costa et al., 2011). Farmers have intensively used pesticides to control these pests. However, chemical control of aphids is no longer effective because of their resistance to insecticides (Carletto et al., 2009).

The use of resistant cultivars can reduce the number of insecticide sprays, and maintain natural enemies. Many crops, including soybean (Kim and Diers, 2013; Conzemius et al., 2019), melon (Liang et al., 2015; Boissot et al., 2016), and tomato (Nalam et al., 2019), have been developed that exhibit natural resistance to aphids. The two basic hostplant resistance to the insect-pests infestation are antixenosis and antibiosis (Niks et al., 2011; Natukunda et al., 2019). Antibiosis interferes with aphid growth, survival, and fecundity, while antixenosis influences aphid behavior, including plant choice and feeding on the sieve elements (Niks et al., 2011). However, strong antibiosis can also affect aphid behavior (Nalam et al., 2019).

Several test methods have been described for identification of insect pests infestation in the host species plants including: whole plant (Klingler et al., 2005; Michel et al., 2010; da-Costa et al., 2011), detached leaf (Michel et al., 2010; Daryanto et al., 2017), leaf disc (Maharijaya et al., 2011), and clip cage (Firdaus et al., 2012; Saberski et al., 2016; Rasool et al., 2017; Sun et al., 2020). The screening methods should be easy to conduct, generate accurate results, reproducible, time-efficient, and requiring little space to be used in the breeding program. However, studies are lacking the evaluation of in vivo vs. in 
vitro tests within the CA infestation in chili pepper. The present study aimed to develop a reliable and practical screening protocol in chili peppers for aphids resistance in tropical areas.

\section{MATERIALS AND METHODS}

\section{Plant material}

The research was conducted from October 2020 to February 2021 in a greenhouse at the Gunung Putri, Bogor, West Java, Indonesia. Chili pepper genotypes were provided by the Department of Agronomy and Horticulture, IPB University, Bogor, Indonesia. In total, seven chili pepper genotypes belong to $C$. annuum species namely IPB C3, IPB C12, IPB C15, IPB C20, IPB C313, IPB C367, and IPB C371, were used. Each genotype was sown in a seedling tray ( 72 holes) and then after 14 days of sowing, the plants were transferred to a pot with size $5.5 \mathrm{~cm} \times 7$ $\mathrm{cm}$. The planting media used was a mixture of cocopeat and husk charcoal with a ratio of $1: 1 \quad(\mathrm{v} / \mathrm{v})$ without insecticide treatment. For fertilizers application, the AB-mix nutrition was used with the concentration of $1000 \mathrm{ppm}$, three times a week. In chili pepper plants, all the screening tests were conducted at the seedling phase and early vegetative stages.

\section{Aphids rearing}

The cotton aphids population was taken from chili pepper fields and then reared on susceptible chili genotype (IPB C313) inside the insect-tight boxes. The aphids colony was maintained in a standard tropical greenhouse under the same conditions as the chili pepper genotype plants. The Aphid population was also transferred to other susceptible chili pepper plants when the host plant quality become poor due to the high aphid population. Colonies of CA were reared for several generations to sufficiently increase the population for infestation. A soft brush was used to transfer wingless aphids (apterous) into the experimental unit.

\section{Screening methods}

\section{Seedling cage test}

The seedling cage test was a whole plant assay at the seedling stage. The evaluation was carried out under greenhouse conditions. Approximately four weeks after sowing, each plant was infested with one wingless adult CA using a wet brush enclosed in an aphid-proof cage. In each chili pepper genotype, four plants were used with four replications in a randomized completed block design (RCBD). Each plant was covered with a modified plastic cup. The colony numbers were counted after one day of infestation (DAI) and seven DAI using a magnifying glass. After testing, the plant organs and aphids were soaked in soapy water to avoid uncontrolled infestation.

\section{Detached leaf test}

The detached leaf test was performed as described by Daryanto et al. (2017). Briefly, the experimental design consisted of four randomized blocks, each comprising seven genotypes grown in a pot and each experimental unit involved four plants per line. The leaf of each plant was taken from fully opened leaves and placed in a closed container $(6 \mathrm{~cm} \times 4 \mathrm{~cm})$ with wet cotton and ventilated by insect nets made of organza fabric. The environmental conditions were kept at 28 ${ }^{\circ} \mathrm{C} \pm 2{ }^{\circ} \mathrm{C}$ and $70 \% \pm 10 \%$. Initial infestation placed one apterous adult for 24 hours and five 1 day old nymphs were produced by an adult aphids on detached leaf which were then used for infestation. The remaining day-old nymphs were used to evaluate for the survival rate and the number of aphids colonies until seven days (Michel et al., 2010). The Survival rate was determined by dividing the number of living aphids by the total colony of aphids in the detached leave. The number of aphids colonies was calculated 
as dead and alive aphids after seven days of infestation.

\section{Clip cage test}

The rings of foam-floating material were used, commonly called swimming pool needles, which are made of polyethylene foam. The foam clip cage is light, durable, easily transported, cheaper, and easily used in field experiments (Haas et al., 2018). Each clip cage consisted of two discs of foam tubes, i.e., one for confining the aphids and the other supporting the clip. The clip cage was prepared using circular with an outer diameter of $4 \mathrm{~cm}$, an inner diameter of $2 \mathrm{~cm}$, and a thickness of $1 \mathrm{~cm}$. Air circulation was provided with an organza fabric on both clips, glued with a non-toxic glue stick. Each plant was given one pair of foam clip cage then clamped by pins. One wingless imago was kept infested for seven days (Hanson et al., 2016). The environmental conditions were kept as per standard tropical greenhouse. The evaluation was carried out for the number of imago, nymphs, and formation of winged aphids.

\section{Comparison of vegetative and generative stages}

Plant stage comparison used clip cage test. Approximately vegetative and generative stages were four and eight weeks after sowing, respectively. Chili pepper cultivar IPB C313 was used as a susceptible genotype and IPB C367 as a putative resistance genotype. Each experimental unit involved four plants per line. Each plant received three foam clip cages containing one adult wingless CA obtained from a rearing on the genotype IPB C313. After evaluation, the observations were recorded as described in the clip cage test.

\section{Heritability estimation}

The broad heritability ( $\mathrm{h}^{2}{ }_{\mathrm{bs}}$ ) value for each test was estimated by using variance components obtained from analysis of variance (ANOVA) using the following formulas:

$$
\boldsymbol{h}_{b s}^{2}=\frac{\sigma^{2} \mathbf{g}}{\sigma^{2} P} \times 100 \%
$$

where;

$$
\begin{gathered}
\text { Environmental variance }\left(\sigma^{2} e\right)=\text { Error } \\
\text { mean square }
\end{gathered}
$$

Genetic variance $\left(\sigma^{2} g\right)=$ (Genotypes

mean square - Error mean square $) / r$

Phenotypic variance $\left(\sigma^{2} \mathrm{p}\right)=\sigma^{2} \mathrm{~g}+\left(\sigma^{2} \mathrm{e} / r\right)$

$r=$ Number of replications

\section{Statistical analysis}

Bartlett's and Normality tests were performed at $P \leq 0.05$ level of significance to meet the assumption $\varepsilon i j \sim N\left(0, \sigma^{2}\right)$; error normal spread, the mean $\mu$, and variance homogeneous. Furthermore, the data were tested by ANOVA (F-test), when the treatments (Chili pepper genotypes) were significantly different, it was followed by the least significant difference (LSD) test at a $5 \%$ level of significance. Pearson correlation was calculated to compare the different test methods. The Student's ttest was used to determine the differences between the plant stages at a $5 \%$ level of significance. The statistical analyses were done using Microsoft Excel 2013, R studio 1.2.1, and Minitab 14.

\section{RESULTS}

\section{Seedling cage test}

In the seedling cage test, the aphid population were recorded at 1 DAI (days after infestation) and 7 DAI. The chili genotypes varied from one another in terms of the number of aphids per plant. 
Table 1. Means of cotton aphids population within seedling cage test at one and seven days after infestation.

\begin{tabular}{lcc}
\hline Genotypes & One DAI & Seven DAI \\
\hline IPB C3 & $8.11 \mathrm{a}$ & $75.42 \mathrm{a}$ \\
IPB C12 & $5.17 \mathrm{a}$ & $51.50 \mathrm{~b}$ \\
IPB C15 & $6.92 \mathrm{a}$ & $74.28 \mathrm{a}$ \\
IPB C20 & $4.36 \mathrm{a}$ & $40.13 \mathrm{~b}$ \\
IPB C313 & $5.75 \mathrm{a}$ & $79.42 \mathrm{a}$ \\
IPB C367 & $5.15 \mathrm{a}$ & $38.83 \mathrm{~b}$ \\
IPB C371 & $5.06 \mathrm{a}$ & $82.18 \mathrm{a}$ \\
\hline
\end{tabular}

One DAI: One day after infestation, Seven DAI: Seven days after infestation. Different letters in the same column indicated a significant difference between genotypes based on LSD's test at level $P \leq 0.05$.

Chili genotypes IPB C367, IPB C20, and IPB $\mathrm{C} 12$ had lower number of aphids at 7 DAI, i.e., 38.83, 40.13, and 51.50 aphids per plant, respectively, compared to the rest However, genotypes IPB C3, IPB C313, and IPB C371 had the higher number of aphids ranging from 74 to 82 aphids per plant. There was no difference $(P=0.146)$ in the number of nymphs produced at one-day after infestation (1 DAI) (Table 1).

\section{Detached leaf test}

The responses of seven chili pepper genotypes on detached leaf testing to CA infestation after 1 DAI and 7 DAI are presented in Table 2 . There was no difference in the number of nymphs produced after 1 DAI in all the chili genotypes $(P=0.06)$. After 7 DAI, there was a difference $(P=<0.0001)$ in the number of aphids per leaf or aphid's colony on the chili genotypes. Genotypes IPB C20 and IPB C637 showed significantly reduced CA colonies compared to other genotypes, i.e., IPB C3, IPB C12, IPB C15, IPB C313, and IPB C371 genotypes. The survival rate of aphids showed no dignificant difference ( $P$ $=0.227$ ) with the values ranged from $0.51-0.86$.

\section{Clip cage test}

We could differentiate CA reproduction in all genotypes by clip cage test. Imago and nymphs were clearly distinguishable in size and color. Imago tended to have a darker color, and the nymphs were bright yellow. Chili pepper genotypes IPB C20 and IPB C367 significantly had lower number of aphid colonies compared to five other genotypes after 7 DAI (Table 3 ). Genotypes IPB C20 and IPB C367 had a low infestation category ranging from 5155 aphids per leaf, while IPB C12, IPB C3, and IPB C371 showed the higher infestations with a range of 64-117 aphids

Table 2. Means of the cotton aphid population and survival rate within detached leaf one and seven days after infestation.

\begin{tabular}{cccc}
\hline Genotypes & One DAI & Seven DAI & Survival rate \\
\hline IPB C3 & $5.60 \mathrm{a}$ & $32.67 \mathrm{~b}$ & $0.83 \mathrm{a}$ \\
IPB C12 & $5.93 \mathrm{a}$ & $32.40 \mathrm{~b}$ & $0.72 \mathrm{a}$ \\
IPB C15 & $5.83 \mathrm{a}$ & $29.60 \mathrm{~b}$ & $0.72 \mathrm{a}$ \\
IPB C20 & $3.43 \mathrm{a}$ & $11.47 \mathrm{c}$ & $0.51 \mathrm{a}$ \\
IPB C313 & $5.83 \mathrm{a}$ & $46.13 \mathrm{a}$ & $0.83 \mathrm{a}$ \\
IPB C367 & $4.93 \mathrm{a}$ & $17.53 \mathrm{c}$ & $0.75 \mathrm{a}$ \\
IPB C371 & $5.57 \mathrm{a}$ & $30.73 \mathrm{~b}$ & $0.86 \mathrm{a}$ \\
\hline
\end{tabular}

One DAI: One day after infestation, Seven DAI: Seven days after infestation. Different letters in the same column indicated a significant difference between genotypes based on LSD's test at the level of $P \leq 0.05$. 
Table 3. Means of the cotton aphid population within clip cage after seven days of infestation.

\begin{tabular}{lllll}
\hline Genotypes & Nymph & Imago & Winged aphid & Total aphids per leaf \\
\hline IPB C3 & $65.19 \mathrm{bc}$ & $21.15 \mathrm{bc}$ & $4.94 \mathrm{a}$ & $89.48 \mathrm{bc}$ \\
IPB C12 & $84.88 \mathrm{ab}$ & $22.83 \mathrm{bc}$ & $4.98 \mathrm{a}$ & $111.00 \mathrm{ab}$ \\
IPB C15 & $89.43 \mathrm{ab}$ & $25.54 \mathrm{ab}$ & $3.75 \mathrm{a}$ & $117.06 \mathrm{ab}$ \\
IPB C20 & $39.93 \mathrm{~d}$ & $13.41 \mathrm{c}$ & $4.25 \mathrm{a}$ & $55.39 \mathrm{~d}$ \\
IPB C313 & $103.23 \mathrm{a}$ & $33.28 \mathrm{a}$ & $6.42 \mathrm{a}$ & $139.54 \mathrm{a}$ \\
IPB C367 & $32.73 \mathrm{~d}$ & $15.00 \mathrm{c}$ & $5.58 \mathrm{a}$ & $50.93 \mathrm{~d}$ \\
IPB C371 & $44.43 \mathrm{~cd}$ & $16.00 \mathrm{bc}$ & $4.38 \mathrm{a}$ & $63.55 \mathrm{~cd}$ \\
\hline
\end{tabular}

Different letters in the same column indicated significant differences between the chili pepper genotypes based on $\mathrm{LSD}_{0.05}$.

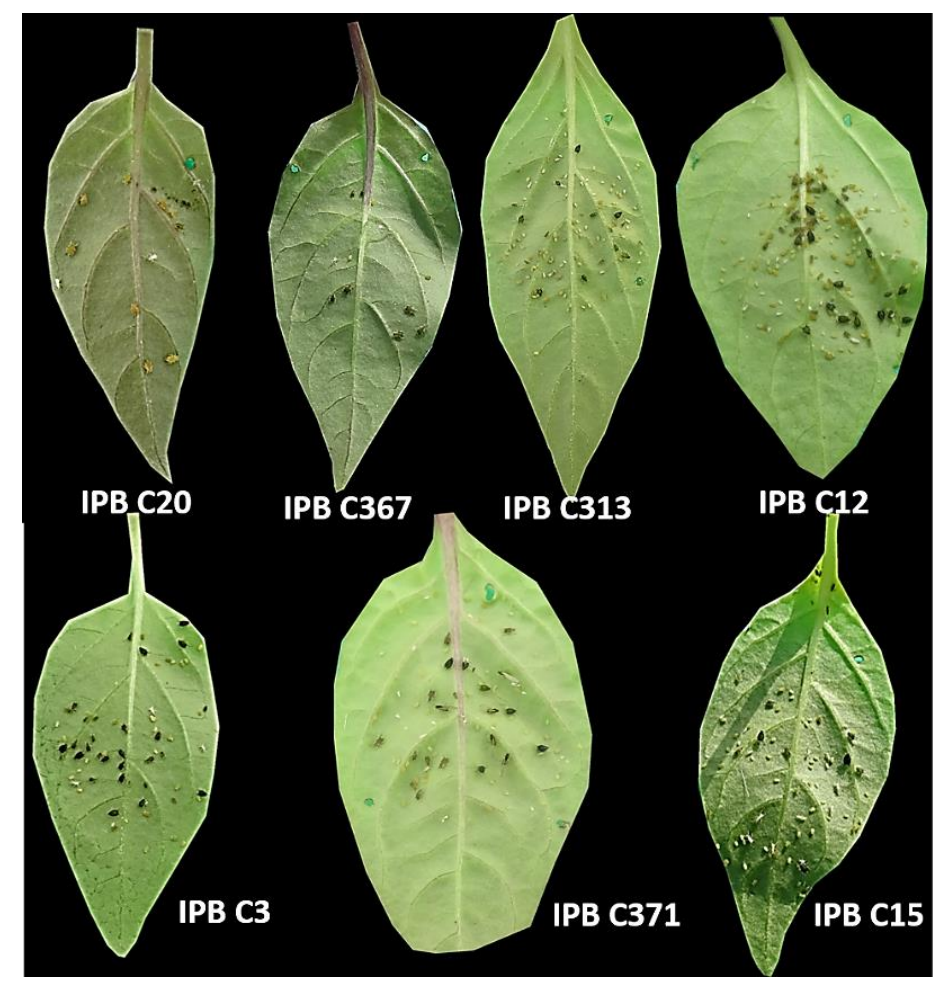

Figure 1. The appearance of cotton aphids infestation on chili pepper genotypes after seven days of infestation by clip cage test. Genotypes IPB C20 and IPB C367 showed low cotton aphids infestation; Genotypes IPB C313, IPB C12, IPB C3, IPB C371, and IPB C5 showed the highest cotton aphids infestation after seven days of infestation.

per leaf. Genotype IPB C313 was identified as the most susceptible phenotype to CA infestation with an increased number of infestations (140 CA per leaf). Genotype IPB C313 was also used as a host for aphid's culture in aphids rearing culture. In line with the total CA per leaf, the number of imago and nymph numbers showed significant differences among the test genotypes, while the winged $C A$ showed no difference at 7 DAI $(P=0.816)$. The appearance and behavior of each chili pepper genotype can be seen in Figure 1. 


\section{Comparison of vegetative and generative stages}

Based on the initial screening methods, it was decided to focus further efforts on the clip cage test to evaluate the plant stage because it was considered to have the flexibility to the plant stage. The responses of the host, resistant, and susceptible genotypes were compared in the vegetative and generative stages after seven days of aphid infestation. The differences in cotton aphid colonies on vegetative and generative stages were not significant on chili pepper cultivars, i.e., IPB C313 ( $t=0.16, P=0.880)$ and IPB C367 $(t=0.83, P=0.446)$.

\section{Comparison of screening tests}

The variance and heritability components of the chili genotypes on the cotton aphids infestation were presented in Table 4. The heritability values generated from three screening methods on aphids population ranged from 90\%-91\%. There was a significant positive correlation between the test methods (seedling cage, detached leaf, and clip cage tests) for the number of aphids after 7 DAI (Table 5). The significant correlation was shown by detached leaf method with seedling cage $(r=0.78, P \leq 0.05)$ and detached leaf with clip cage test $(r=0.84, P \leq 0.05)$.

Table 4. Variance components and heritability values of chili pepper resistance to cotton aphids infestation in the seedling cage, detached leaf, and clip cage tests.

\begin{tabular}{lllll}
\hline Screening methods & $\sigma^{2}{ }_{e}$ & $\sigma^{2}{ }_{q}$ & $\sigma^{2}$ & $h^{2}{ }_{b s}(\%)$ \\
\hline Seedling cage test & 93.543 & 328.443 & 359.624 & 91 \\
Detached leaf test & 0.587 & 1.101 & 1.219 & 90 \\
Clip cage test & 460.107 & $1,059.98$ & $1,175.01$ & 90 \\
\hline
\end{tabular}

$\sigma^{2} e$ : Environmental variance, $\sigma^{2} g$ : Genetic variance, $\sigma^{2} p$ : Phenotypic variance, $h_{b s}^{2}$ : Broad sense heritability

Table 5. Pearson correlation and its significance among three infestation methods in total colonies parameter at seven days of infestation.

\begin{tabular}{lcc}
\hline Screening tests & Seedling cage test & Clip cage test \\
\hline Clip cage test & $0.54^{\mathrm{NS}}$ & - \\
Detached leaf test & $0.79 *$ & $0.84 *$ \\
\hline
\end{tabular}

*Correlation is significant at the 0.05 level (two-tailed). NS: Not significant, *Significant at $p<0.05$.

\section{DISCUSSION}

\section{Screening tests effect on aphids population}

All the screening tests showed high heritability values using cotton aphids (Table 5), indicating that the evaluated chili pepper genotypes could be used to determine the effective screening methods. All the screening tests were performed at the seedling phase. There were non-significant differences between the seedling phase (vegetative) and generative stage in response to $C A$ infestation (Figure 2). The seedling phase required less space, more uniformly than generative plants, and can be performed soon after sowing (Niks et al., 2011). The significant correlation among the screening tests provides the information that it is possible to use either detached leaf or clip cage to screen chili pepper genotypes for resistance to aphids. Using chili peppers plant leaves either detached or caged could facilitate the evaluation of host plant resistance to cotton aphids. Maharijaya et al. (2011) reported similar results in vitro and in vivo methods developed to screen chili peppers 


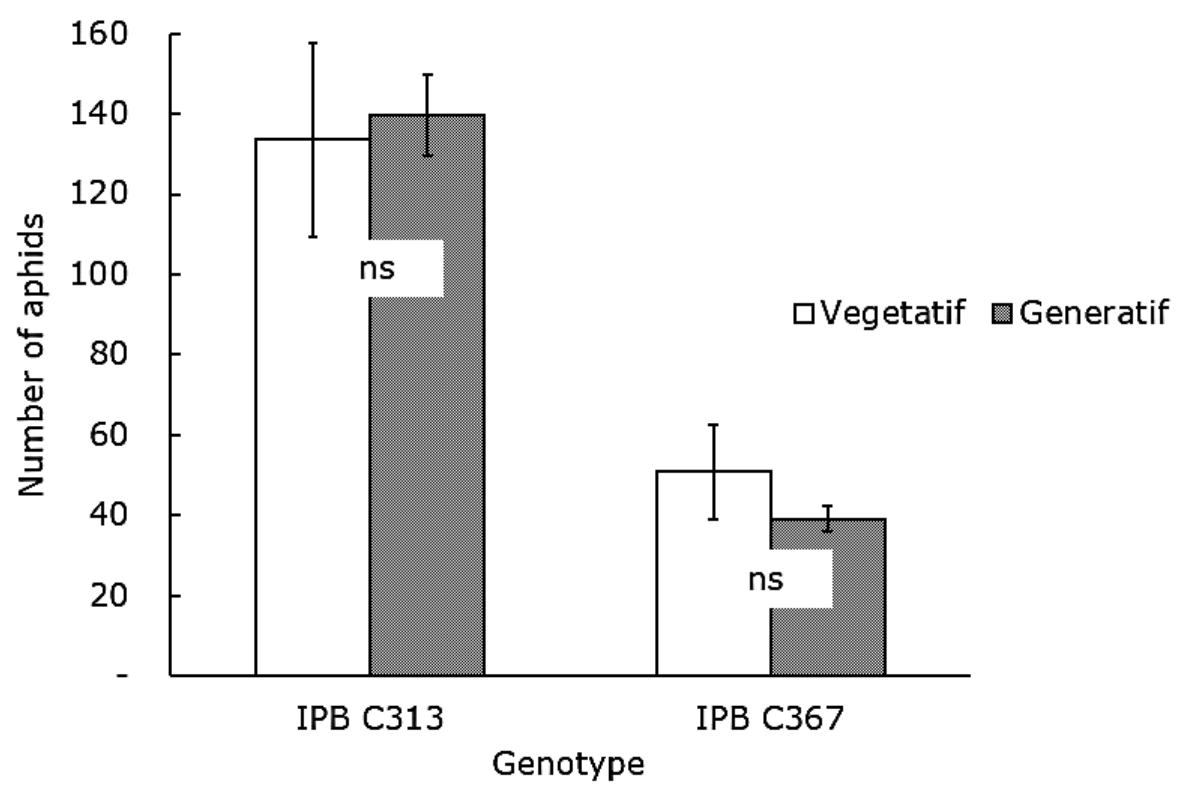

Figure 2. Plant stage response to the cotton aphids infestation in chili pepper genotypes IPB C313 and IPB C367. NS: not significant for a t-student test at $P \leq 0.05$. Bar indicated the standard error of the mean (SEM).

genotypes for resistance to thrips with high heritability values and were strongly correlated.

Past studies reported that in vitro tests such as detached leaf and leaf disc could be used as an appropriate screening method for insect pests than the whole plant (Maharijaya et al., 2011; Vosman et al., 2018). Other studies also reported that detached leaves cannot replace the whole plant for the evaluation of soybean genotypes for resistance to aphids (Michel et al., 2010; Lagos-Kutz et al., 2020). The detached leaf is usually used for the evaluation of the life table parameters of aphids (Satar et al., 2008).

The clip cage could be an appropriate screening method to evaluate chili peppers resistance to aphids because it combines a detached leaf and the whole plant assay, and thus avoiding other tests which require more space, time, and energy consumed. Many researchers have used clip cage tests over the years in antibiosis-based resistance to aphid infestation (Blua and Perring, 1992; Saberski et al., 2016; Rasool et al., 2017; Sun et al., 2020). Clip cages potentially reduced the damage to the plant and are perfectly used in the laboratory, glasshouse, and in the open field (Haas et al., 2018).

In a plant breeding program, the shortest screening method is needed and more desirable. Present results showed that aphid colonies could be well differentiated at 7 DAI both for the resistant and susceptible chili pepper genotypes. Esmaeili-Vardanjani et al. (2014) reported that common bean resistance to $A$. fabae could be identified at 7 DAI. Tilmon et al. (2011) reported double time (6-7 DAI) for Aphis glycines population on the soybean. Evaluation of cotton aphids colonization in melon plants was carried out after seven days of infestation (Boissot et al., 2016).

In the screening methods used for chili pepper antibiosis resistance to cotton aphids infestation, some advantages and disadvantages were observed (Table 6). Each screening test required different environmental conditions, the material used, the damage rate of the plant, and the easiness in evaluation. The seedlings were used for the whole plant assay and 
Table 6. Comparison among screening tests against aphids infestation.

\begin{tabular}{cllll}
\hline No. & Parameters & Detached leaf & Clip cage & Seedling cage \\
\hline 1 & Types & In vitro & In vivo & In vivo \\
2 & Test location & Laboratory & Greenhouse & Greenhouse \\
3 & Monitoring & Easy & Medium & Medium \\
4 & Plant Sample & Non-destructive & Non-destructive & Destructive \\
5 & Evaluation & Easy & Easy & Medium-Hard \\
6 & Material cost & Low & Low & Low \\
7 & Heritability value & High & High & High \\
\hline
\end{tabular}

modified the plastic cup as a cage. The seedling cage test was destructive because it needed to cut off all leaves to count the entire aphid population. Aphids could be trapped and die by water condensation on the cage during the day. So it was necessary to provide a shading net to reduce the light intensity. The cages made are suitable only at the seedling stage, around 4 to 5 weeks after sowing. Therefore, if the chili peppers genotypes have vigor growth, then there would be problems with this method.

With a detached leaf test, the leaves were damaged by fungus. The leaves become damaged due to the accumulation of honeydew. Honeydew was reported as a good medium for the development of sooty mold (Kinyanjui et al., 2016) which can interfere with photosynthesis and then affect the plant quality (Tilmon et al., 2011). Lagos-Kutz et al. (2020) reported inconsistent responses of soybean aphids using detached leaves compared to whole plant assay. The retention of resistance to soybean aphids on detached leaves depends on the source of resistance (Michel et al., 2010).

With the clip cage test, there was no effect on aphid reproduction. The foam clip-cages were used to evaluate the aphids infestation. Foam clip-cage is a light material, and there was no need for plant stakes to support the clip-cages during the experiment. The foam clip cage adapted very well to the leaves, both at vegetative and generative plant stages and the pressure applied on the leaf could be controlled well. According to Haas et al. (2018), foam clip cages were cheaper and the lower escape rate of aphids (6\% escape) was less than the classic clip cage (40\% escape).

\section{Chili pepper genotypes response in resistance to aphids}

The reproduction rate of cotton aphids was observed in chili pepper genotypes at the seedling stage with detached leaf and clip cage tests. In this study, the developed test was antibiosis-based resistance of chili peppers to CA infestation. A wingless CA could produce 4 to 8 nymphs at in vivo test (Table 1 ) and 3 to 6 at in vitro test (Table 2) after 24 hours. Nymph parameters after one day of infestation did not show any difference between resistant and susceptible chili peppers genotypes both in the seedling cage and detached leaf tests. The study also indicated that the previous host influenced the one-day colony of CA. An imago CA produced 3 to 5 nymphs per day on chili pepper genotypes recorded through detached leaf test (Daryanto et al., 2017).

The three developed screening tests were able to distinguish the reproductive ability of cotton aphids. Chili pepper genotypes IPB C20 and IPB C367 showed resistance with fewer numbers of aphids infestation than the other five genotypes after 7 DAI. These results confirmed our previous study where the genotype IPB C20 was found resistant to cotton aphids infestation, while the three other genotypes, i.e., IPB C313, IPB C15, and IPB C12 were recognized as susceptible in the detached leaf test (Daryanto et al., 2017). There was still 
limited information regarding the source of chili pepper resistance to CA compared to green peach aphid (GPA) (Parisi et al., 2020). Sun et al. (2020) reported a chili pepper genotype that was resistant against GPA infestation, but its resistance to cotton aphids was not confirmed. According to Tálaga-Taquinas et al. (2020), the cotton aphids species reached its adult state faster than GPA in chili peppers.

In addition to identifying resistant chili pepper genotypes, it is also important to be able to identify susceptible genotypes that could be used as an effective and efficient host plant in the rearing programs. The chili pepper genotype IPB C313 was identified as an effective and efficient host in the aphid's culture because it was consistent as a highly susceptible genotype in all the screening tests. Genotype IPB C313 also had fast growth, vigorous, and produced large numbers of seeds for next propagation. Host plants have a crucial role in the success of the screening to insect pest resistance. For example, in the other chili pepper screening programs, the GPA maintained lower survival and reproduction on cabbage than chili peppers (Sun et al., 2018).

The chili pepper genotype from $C$. annnum species became our focus in the resistance to cotton aphids. $C$. annuum is the most popular species grown by farmers compared to other species (Ministry of Agriculture Republic Indonesia, 2021). Finding a source of resistance in this species will make it easier to transfer these resistance genes into other commercial cultivars through breeding. The source of GPA resistance was reported in the species $C$. baccatum (Sun et al., 2018) and C. pubeccent (Bosland and Ellington, 1996). The identified chili pepper resistant genotypes belong to different species, and it would be difficult to be crossed. There were barriers in inter-specific crossing between C. annuum and C. baccatum for introgression of resistance gene (Lee et al., 2016). The present results showed considerable variation for resistance to aphids in the species $C$. annuum that can be exploited in breeding programs and further genetic studies related to aphid resistance in chili peppers.

\section{CONCLUSIONS}

All the deployed screening tests had high heritability and a strong correlation. It means that the evaluated chili pepper genotypes could be used to determine the effective screening method. The correlation between the detached leaf and clip cage tests was significant. Therefore, the clip cage test could be used as a reliable and practical screening test for the assay of chili peppers resistance to CA infestation. This information will be very useful for developing aphid-resistant cultivars.

\section{ACKNOWLEDGeMENTS}

This study was supported by a research grant with contract number: 1976/IT3.L1/PN/2021 in 2021 provided by the National Agency for Research and Innovation, Indonesian Ministry of Research and Technology, Indonesia.

\section{REFERENCES}

Amamoto S, DJarwaningsih $\mathrm{T}$, Wiriadinata $\mathrm{H}$ (2013). Notes on economic plants Capsicum pubescens (Solanaceae) in Indonesia: Its history, taxonomy, and distribution. Eco. Bot. 67(2): 161-170.

Blanchard S, Lognay G, Verheggen F, Detrain C (2019). Today and tomorrow: Impact of climate change on aphid biology and potential consequences on their mutualism with ants. Physiol. Entomol. 44(2): 77-86.

Blua MJ, Perring TM (1992). Alatae production and population increase of aphid vectors on virus-infected host plants. Oecologia 92(1): 65-70.

Boissot N, Thomas S, Chovelon V, Lecoq H (2016). NBS-LRR-mediated resistance triggered by aphids: Viruses do not adapt; aphids adapt via different mechanisms. BMC Plant Biol. 16(25): $1-12$. 
Bosland PW, Ellington JJ (1996). Comparison of Capsicum annuum and $C$. pubescens for antixenosis as a means of aphid resistance. Hort. Sci. 31(6): 10171018.

Carletto J, Lombaert E, Chavigny P, BrÉvault T, Lapchin L, Vanlerberghe-Masutti $F$ (2009). Ecological specialization of the aphid Aphis gossypii Glover on cultivated host plants. Mol. Ecol. 18(10): 2198-2212.

Conzemius SR, Hesler LS, Varenhorst AJ, Tilmon KJ, Peairs F (2019). Resistance of soybean plant introductions to three colonies of Soybean Aphid (Hemiptera: Aphididae) biotype 4. J. Econ. Entomol. 112(5): 2407-2417.

da Costa JG, Pires EV, Riffel A, Birkett MA, Bleicher E, Sant'Ana AEG (2011). Differential preference of Capsicum spp. cultivars by Aphis gossypii is conferred by variation in volatile semiochemistry. Euphytica 177(3): 299-307.

Daryanto A, Syukur M, Hidayat P, Maharijaya A (2017). Antixenosis and antibiosis based resistance of chili pepper to melon aphid. J. Appl. Hort. 19(2): 147151.

Esmaeili-Vardanjani M, Askarianzadeh A, Saeidi Z, Hasanshahi G, Karimi J, Nourbakhsh SH (2014). Antixenosis resistance to Aphis fabae Scopoli (Hemiptera:Aphididae) in bean cultivars. Arch. Phytopathol. Plant Prot. 47(1): 51-58

Fereres A, Avilla C, Collar JL, Duque M, Fernandez-Quintanilla C (1996). Impact of various yield-reducing agents on open-field sweet peppers. Environ. Entomol. 25: 983-986.

Firdaus S, van Heusden AW, Hidayati N, Supena EDJ, Visser RGF, Vosman B (2012). Resistance to Bemisia tabaci in tomato wild relatives. Euphytica 187(1): 31-45.

Haas J, Lozano ER, Poppy GM (2018). A simple, light clip-cage for experiments with aphids. Agric. For. Entomol. 20(4): 589-592.

Hanson AA, Orf JH, Koch RL (2016). Sources of soybean aphid resistance in earlymaturing soybean germplasm. Crop Sci. 56: 154-163.

Kim KS, Diers BW (2013). The associated effects of the soybean aphid resistance gene Rag-2 from PI 200538 on agronomic traits in soybean. Crop Sci. 53(4): 1326-1334.
Kinyanjui G, Khamis FM, Mohamed S, Ombura LO, Warigia M, Ekesi S (2016). Identification of aphid (Hemiptera: Aphididae) species of economic importance in Kenya using DNA barcodes and PCR-RFLP-based approach. Bull. Entomol. Res. 106(1): 63-72.

Klingler J, Creasy R, Gao L, Nair RM, Calix AS, Jacob HS, Edwards OR, Singh KB (2005). Aphid Resistance in Medicago truncatula involves antixenosis and phloem-specific, inducible antibiosis, and maps to a single locus flanked by NBS-LRR resistance gene analogs 1 . Plant Physiol. 137: 1445-1455.

Lagos-Kutz D, Pawlowski ML, Diers BW, Purandare SR, Tilmon KJ, Hartman GL (2020). Virulence of soybean aphid, Aphis glycines (Hemiptera: Aphididae) clones on detached leaves and whole plants. J. Kansas Entomol. Soc. 92(3): 497-511.

Lee YR, Yoon JB, Lee J (2016). A SNP-based genetic linkage map of Capsicum baccatum and its comparison to the Capsicum annuum reference physical map. Mol. Breed. 36(61): 1-16.

Liang D, Hu Q, Xu Q, Qi X, Zhou F, Chen X (2015). Genetic inheritance analysis of melon aphid (Aphis gossypii Glover) resistance in cucumber (Cucumis sativus L.). Euphytica 205(2): 361367.

Loughner RL, Warnock DF, Cloyd RA (2005). Resistance of greenhouse, laboratory, and native populations of western flower thrips to spinosad. Hort. Sci. 40(1): 146-149.

Maharani Y, Hidayat P (2019). Aphids (Hemiptera: Aphididae) in the agricultural habitat in Indonesia. Asian J. Agric. Biol. 7: 277-285.

Maharijaya A, Vosman B, Steenhuis-Broers G, Harpenas A, Purwito A, Visser RGF, Voorrips RE (2011). Screening of pepper accessions for resistance against two thrips species (Frankliniella occidentalis and Thrips parvispinus). Euphytica 177(3): 401-410.

Michel AP, Mian MAR, Davila-olivas NH (2010). Detached leaf and whole plant assays for soybean aphid resistance: differential responses among resistance sources and biotypes. Plant Resist. 103(3): 949-957.

Ministry of Agriculture Republic Indonesia (2021). Basic data of agricultural statistics. https://www.pertanian. 
go.id/home/?show=page\&act=view\&id $=61$.

Nalam V, Louis J, Shah J (2018). Plant defense against aphids, the pest extraordinaire. Plant Sci. 279: 96-107.

Natukunda MI, Parmley KA, Hohenstein JD, Assefa T, Zhang J, Macintosh GC, Singh AK (2019). Identification and genetic characterization of soybean accessions exhibiting antibiosis and antixenosis resistance to Aphis glycines (Hemiptera: Aphididae). J. Econ. Entomol. 112(3): 1428-1438.

Niks R, Parlevliet J, Lindhout P, Bai Y (2011). Breeding Crops with Resistance Disease and Pests. Netherlands: Wageningen Academic.

Parisi M, Alioto D, Tripodi P (2020). Overview of biotic stresses in pepper (Capsicum spp.): Sources of genetic resistance, molecular breeding and genomics. Int. J. Mol. Sci. 21(7): doi: $10.3390 /$ ijms21072587.

Rasool B, Mcgowan J, Pastok D, Marcus SE, Morris JA, Verrall SR, Hedley PE, Hancock RD, Foyer CH (2017). Redox control of aphid resistance through altered cell wall composition and nutritional quality. Plant Physiol. 175: 259-271.

Saberski ET, Diamond JD, Henneman NF, Levitis DA (2016). Post-reproductive parthenogenetic pea aphids (Acyrthosiphon pisum) are visually identifiable and disproportionately positioned distally to clonal colonies. Peer J. 4: 1-17.

Satar S, Kersting U, Uygun N (2008). Effect of temperature on population parameters of Aphis gossypii Glover and Myzus persicae (Sulzer) (Homoptera: Aphididae) on pepper. J. Plant Dis. Prot. 115(2): 69-74.

Setiawati W, N S, Koesandriani Y, Hasyim A, Uhan T, Sutarya R (2013). Penerapan teknologi pengendalian hama terpadu pada tanaman cabai merah untuk mitigasi dampak perubahan iklim. $J$. Hort. 23(2): 174-183.
Shannag HK, Al-Qudah JM, Makhadmeh IM, Freihat NM (2007). Differences in growth and yield responses to Aphis gossypii Glover between different okra varieties. Plant Prot. Sci. 43(3): 109116.

Smith CM, Chuang WP (2014). Plant resistance to aphid feeding: Behavioral, physiological, genetic and molecular cues regulate aphid host selection and feeding. Pest Manag. Sci. 70(4): 528540.

Storer JR, Van-Emden HF (1995). Antibiosis and antixenosis of chrysanthemum cultivars to the aphid Aphis gossypii. Entomol. Exp. Appl. 77(3): 307-314.

Sun M, Voorrips RE, Steenhuis-Broers G, van't Westende W, Vosman B (2018). Reduced phloem uptake of Myzus persicae on an aphid resistant pepper accession. BMC Plant Biol. 18(1): 1-14.

Sun M, Voorrips RE, Vosman B (2020). Aphid populations showing differential levels of virulence on Capsicum accessions. Insect Sci. 27(2): 336-348.

Syukur M, Sujiprihati S, Yunianti R, Kusumah DA (2010). Evaluasi daya hasil cabai hibrida dan daya adaptasinya di empat lokasi dalam dua tahun. J. Agron. Indonesia 38(1): 43-51.

Tálaga-Taquinas W, Melo-Cerón CI, LagosÁlvarez YB, Duque-Gamboa DN, ToroPerea N, Manzano MR (2020). Identification and life history of aphids associated with chili pepper crops in southwestern Colombia. Univ. Sci. 25(2): 175-200.

Tilmon KJ, Hodgson EW, O'neal ME, Ragsdale ADW (2011). Biology of the soybean aphid, Aphis glycines (Hemiptera: Aphididae) in the United States invasion history and distribution. $J$. Integr. Pest Manag. 2(2): 1-7.

Vosman B, van't Westende WPC, Henken B, van Eekelen HDLM, de Vos RCH, Voorrips RE (2018). Broad spectrum insect resistance and metabolites in close relatives of the cultivated tomato. Euphytica 214(3). doi:10.1007/s10681-018-2124-4. 